\title{
Ovarian Tissue Vitrification as a Method for Ovarian Preservation in Women with Cancer: an Analysis of Granulose Cell Apoptosis
}

\author{
Simpan Beku Korteks Ovarium sebagai Pilihan dalam Upaya Mempertahankan Fungsi \\ Reproduksi Perempuan Penderita Kanker: Sebuah Kajian Apoptosis Sel Granulosa
}

\author{
Budi Wiweko1, Huthia Andriyana', Achmad Aulia ${ }^{2}$ \\ ${ }^{1}$ Department of Obstetrics and Gynecology \\ ${ }^{2}$ Department of Histology \\ Faculty of Medicine University of Indonesia/ \\ Dr. Cipto Mangunkusumo General Hospital \\ Jakarta
}

\begin{abstract}
Objective: To obtain the effective method of ovarian function preservation with granulose cell apoptosis assessment. Ovarian tissue vitrification became a method for ovarian function preservation in women with cancer. This technique can be done anytime without delay on cancer therapy both in prepubertal and unmarried patient. It can also store many primordial follicles. Ovarian tissue vitrification study is still limited to animal test and there are no data about apoptosis assessment after ovarian vitrification in human ovary.
\end{abstract}

Method: This quasi experimental study was held in Department of Obstetrics and Gynecology Faculty of Medicine University of Indonesia - Dr. Cipto Mangunkusumo General Hospital and Fatmawati Hospital Jakarta from March 2012 to May 2015. Ovaries from thirteen women between 31 and 37 years old who underwent oophorectomy with gynecological indication were examined.

Result: There was no morphological difference between follicles from fresh and warmed-vitrified ovaries. The mean protein Bax expression on the fresh ovaries assessed in the form of H-score was 1.66 (SD 0.14) compared with 1.68 (SD 0.13) on the warmedvitrified group $(\mathrm{p}=0.165)$. The mean protein $\mathrm{Bcl}-2$ expression on the fresh ovaries examined in the form of H-score was 1.73 (SD 0.10) compared with 1.71 (SD 0.10) on the warmed-vitrified group $(\mathrm{p}=0.068)$.

Conclusion: Ovarian tissue vitrification does not affect the Bax and Bcl-2 expression on human ovary.

[Indones J Obstet Gynecol 2016; 4-2: 88-92]

Keywords: apoptosis, bax, Bcl-2, ovarian tissue vitrification

\begin{abstract}
Abstrak
Tujuan: Untuk memperoleh upaya mempertahankan fungsi ovarium yang efektif dengan penilaian apoptosis sel granulosa. Simpan beku korteks ovarium menjadi pilihan dalam upaya mempertahankan fungsi reproduksi perempuan penderita kanker karena dengan teknik ini dapat disimpan banyak folikel primordial. Penyimpanan ini dapat dilakukan kapan saja saat siklus haid tanpa penundaan terapi kanker serta pada pasien pra-pubertas dan belum menikah. Penelitian simpan beku korteks ovarium masih terbatas pada hewan coba serta belum terdapat data yang menilai kejadian apoptosis sel granulosa pascasimpan beku korteks ovarium manusia yang dilihat dari ekspresi gen terkait apoptosis.
\end{abstract}

Metode: Penelitian ini merupakan penelitian kuasi eksperimental yang dilaksanakan di Departemen Obstetri Ginekologi Fakultas Kedokteran Universitas Indonesia - RSUPN Dr. Cipto Mangunkusumo dan RS Fatmawati Jakarta dalam rentang waktu Maret 2012 hingga Mei 2015. Korteks ovarium didapatkan dari tiga belas pasien berusia 3137 tahun yang menjalani ooforektomi atas indikasi ginekologis.

Hasil: Secara morfologi, tidak terdapat perbedaan folikel dari korteks ovarium segar dengan korteks ovarium pasca vitrifikasi. Rerata ekspresi protein Bax dari korteks ovarium segar yang dinilai dalam bentuk H-score adalah 1,66 (SD 0,14) dibandingkan 1,68 (SD 0,13) pada ovarium pasca vitrifikasi $(p=0,165)$. Sedangkan, rerata ekspresi protein Bcl-2 dari korteks ovarium segar adalah 1,73 $(S D 0,10)$ dibandingkan 1,71 $(S D 0,10)$ pada ovarium pascavitrifikasi $(p=0,068)$.

Kesimpulan: Simpan beku korteks ovarium terbukti tidak menyebabkan peningkatan ekspresi gen Bax dan Bcl-2.

[Maj Obstet Ginekol Indones 2016; 4-2: 88-92]

Kata kunci: apoptosis, Bax, Bcl-2, simpan beku korteks ovarium

Correspondence: Huthia Andriyana. Department of Obstetrics and Gynecology, Faculty of Medicine University of Indonesia, Jakarta. Telephone: +6281399319951 Email: huthia@gmail.com

\section{INTRODUCTION}

Over the past three decades, there has been a remarkable improvement in the survival rates due to the cancer treatment improvement. In United States, more than 650,000 new female cancer cases were estimated to be diagnosed in $2003 .{ }^{1} \mathrm{Ad}$ vancing in the diagnosis and treatment of child- hood, adolescent and adult cancer have greatly enhanced the life expectancy of premenopausal women with cancer. As a result, there is a growing population of adolescent and adult long-term survivors of childhood cancer. ${ }^{2}$ Ovaries, which are endowed with an irreplaceable number of follicles, are extremely sensitive to cytotoxic drugs that induce an irreversible gonadal damage. ${ }^{1,3}$ 
Ovarian cortex vitrification is one of the promising freezing techniques in order to maintain the reproductive function. Unfortunately, freezing procedure is a process that can cause follicle damage because of the potency to increase the apoptosis process. Assessment of apoptosis by expression of pro and anti-apoptotic proteins can be conducted to determine biomolecular processes occurring intracellular that has been indicated to precede morphological changes. Ovarian cortex vitrification research is still limited in animal experiments and there have been no data to assess the incidence of the granulosa cells apoptosis after human ovarian cortex vitrification.1,3-5 Therefore, this study aims to obtain the effective method of ovarian function preservation with granulose cell apoptosis assessment.

\section{METHODS}

All experimental procedures were approved by the Ethical Research Committee of the Faculty of Medicine University of Indonesia after obtaining written informed consent. We took the ovaries from six women between 30 and 37 years old who underwent oophorectomy due to cervical or breast cancer. Surgeries were performed in the Acute Tertiary Care Hospital in Jakarta during the period of March 2012 to April 2015.

\section{Ovarian Tissue Vitrification}

Ovarian tissue was suspended in $37^{\circ} \mathrm{C}$ phosphate buffered saline (PBS) and transferred to the laboratory within 15 minutes. A tissue slicer (Square Measure, Kitazato, Shizuoka, Japan) was used to cut the ovarian cortex into pieces measuring $10 \times 10 \times 1$ $\mathrm{mm} .6,7$

Two chosen section of ovarian cortexes were divided into two groups. The first group was a control group for assessing Bax and Bcl-2 protein expression using immunohistochemical method. The second group was an experimental group frozen by vitrification technique and followed to thawing process, then Bax and Bcl-2 protein expression were assessed with the same immunohistochemical method to be compared with the first group. After being excised, ovarian cortexes were placed in $15 \mathrm{ml}$ of $\alpha$-MEM (minimum essential medium). Ovarian cortexes were initially equilibrated in $7.5 \%$ ethylene glycol (EG); $7.5 \%$ dimethyl sulfoxide (DMSO) for 25 minutes, followed by a se- cond equilibration in 20\% EG, 20\% DMSO, 0.5 $\mathrm{mol} / \mathrm{l}$ sucrose liquid for 15 minutes. Ovarian cortexes were placed in a minimum volume of solution into a thin metal strip and submerged directly into liquid nitrogen. ${ }^{7}$

\section{Immunohistochemical (IHC) Staining of Bax and BCL-2 Protein in Fresh and Vitri- fied Human Ovarian Tissue}

Bax and Bcl-2 protein staining using IHC were done in fresh and vitrified ovarian cortex from each patient. Immunohistochemical staining was performed using 3 steps polymer detection system of Starr Trek Universal HRP Detection System. The negative control groups were stained using the same method, whereas the first antibody was substituted by PBS. Rabbit anti-human monoclonal Bax and mouse anti-human monoclonal Bcl-2 antibodies were used. All paraffin-embedded samples were deparaffinized and rehydrated. Sections were incubated in $0.5 \% \mathrm{H}_{2} \mathrm{O}_{2}$ to block endogenous peroxides, and then incubated with blocking background sniper to reduce nonspecific binding. The primary antibody was applied and the sections was kept at room temperature overnight. Universal link (secondary monoclonal antibody from rabbit and mouse) were put on for 15 minutes. After incubating with Trek Avidin-horseradish peroxidase to bind antibody with chromogen, sections were stained with DAB (Diaminobenzidintetraacetic acid) for 5-10 minutes.

The expression of Bax and Bcl-2 proteins was identified as diffuse brown cytoplasmic staining. Ovarian cortex apoptosis was assessed semiquantitatively with Bax and Bcl-2 protein expression in primordial follicle, primary follicle and secondary follicle. The number of granulosa cells stained (Pi) in each follicle were counted and the mean Pi from all follicles examined was calculated. We scored the color intensity as weak, moderate, or strong and the final $\mathrm{H}$-score was calculated with the algorithm: $\mathrm{H}$-score $=\sum \mathrm{Pi}(\mathrm{i}+1)$.

\section{Statistical Analysis}

Statistical analysis was performed using Statistical Program for Social Sciences version 20.0. SaphiroWilk test was used to assess the normality distribution. We used paired T-test to compare between H-score. 


\section{RESULTS}

We obtained the samples from thirteen patients between 30 and 37 years of age who underwent oophorectomy due to cervical cancer (stage IB) or breast cancer (Table 1). The mean level of antimullerian hormone (AMH) in these patients was 2.9 (SD 1.6) $\mathrm{ng} / \mathrm{ml}$.

Table 1. Subject Characteristics

\begin{tabular}{lcc}
\hline \hline Characteristics & n (\%) & Mean(SD) \\
\hline Age (years old) & - & $33(1.6)$ \\
Body mass index $\left(\mathrm{kg} / \mathrm{m}^{2}\right)$ & - & $23.6(4.7)$ \\
Parity & & \\
$\quad$ Nuliparity & $3(23.1)$ & - \\
$\quad$ Primiparity & $4(30.8)$ & \\
$\quad$ Multiparity & $6(46.2)$ & \\
AMH level (ng/ml) & - & $2.9(1.6)$ \\
\hline \hline
\end{tabular}

\section{Evaluation of Morphology and Apoptosis of Follicles from Fresh and Warmed-Vitrified Ovaries}
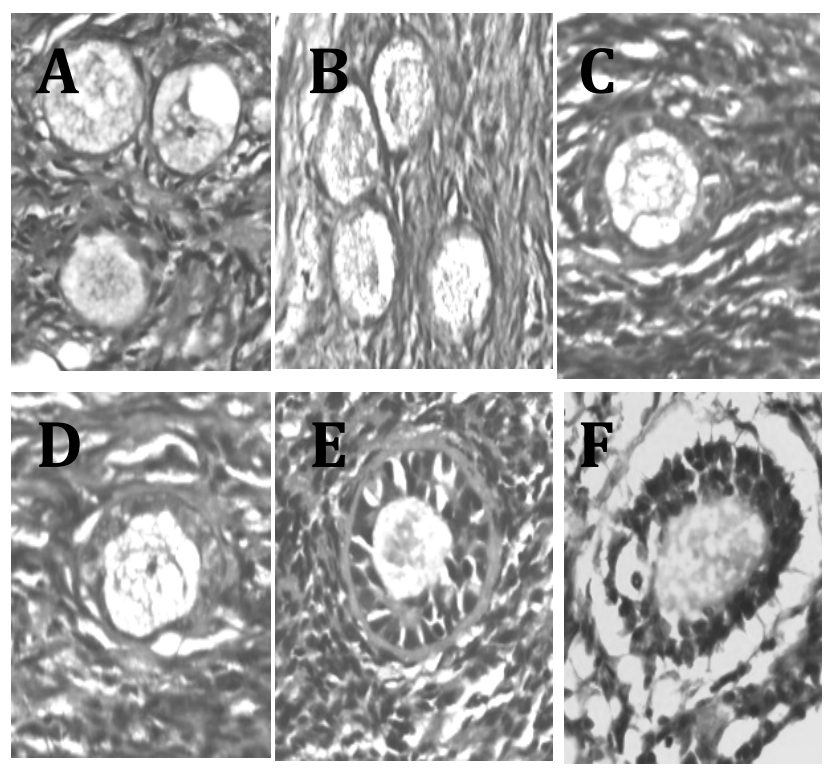

Figure 1. Follicles from fresh and warmed-vitrified ovaries. Primordial follicles (A and B), primary follicles (C and D), secondary follicles (D and E). Description: A, C, E: follicles from fresh ovaries. B, D, F: follicles from warmedvitrified ovaries.
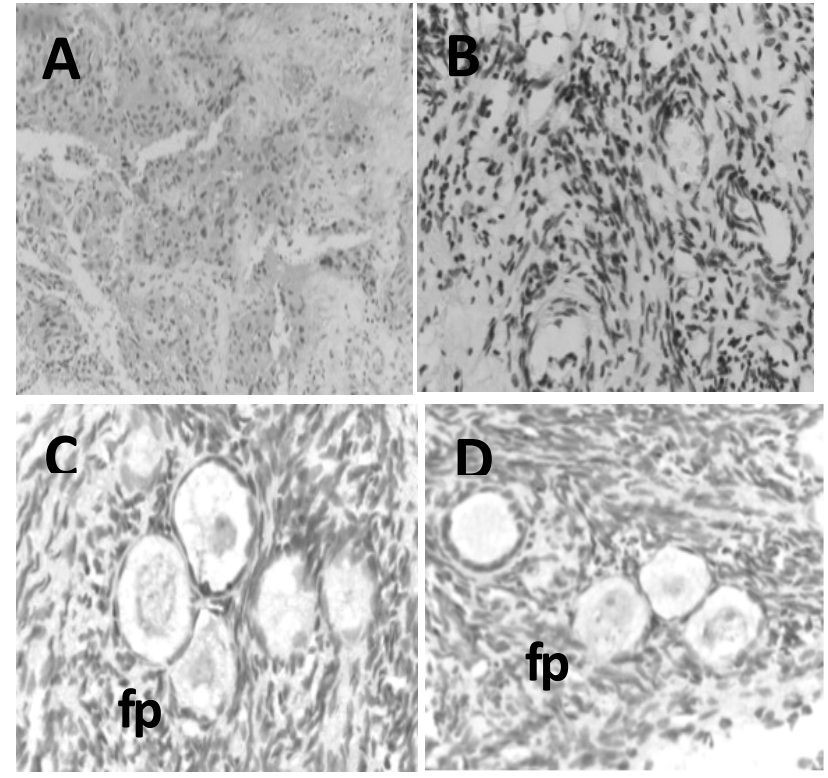

Figure 2. Bax expression on ovarian tissue. A. Bax expression on breast cancer tissue (positive control). B. No visible Bax expression on stromal ovarian tissue (negative control). C. Bax expression on granulosa cells and oocyte with low intensity in fresh ovarian tissue. D. Bax expression on granulosa cells and oocyte with low intensity in warmed-vitrified ovaries. Description: fpr: primordial follicles.
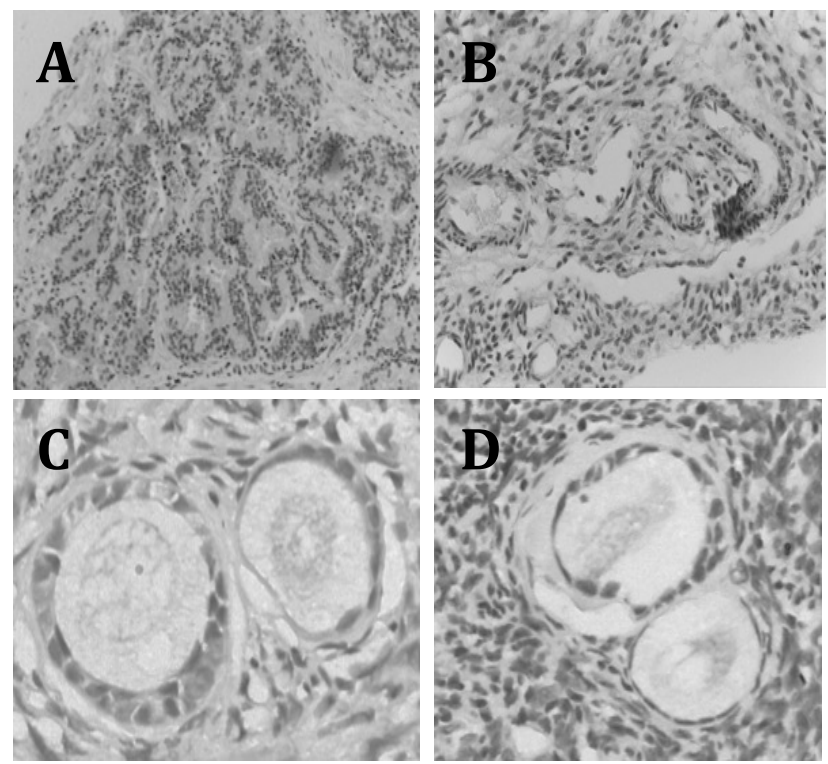

Figure 3. Bcl-2 expression on ovarian tissue. A. Bcl-2 expression on breast cancer tissue (positive control). B. No visible Bcl-2 expression on stromal ovarian tissue (negative control). C. Bcl-2 expression on granulosa cells and oocyte with low intensity in fresh ovarian tissue. D. Bcl-2 expression on granulosa cells and oocyte with low intensity in warmed-vitrified ovaries. Description: fpr: primordial follicles, fp: primary follicle. 
There were no significant morphological differences between follicles from fresh and warmedvitrified ovaries based on examinatons of basal membrane, granulosa cells and oocyte (Figure 1). This finding also supported by the result of IHC staining of Bax and Bcl-2 protein expression, which also showed no alteration (Figure 2 and 3). The mean $\mathrm{H}$-score for Bax on fresh ovaries was 1.7 (SD 0.1 ) versus 1.7 (SD 0.1) on warmed-vitrified ovaries $(\mathrm{p}=0.165)$. The mean $\mathrm{H}$-score for Bcl-2 on fresh ovaries was 1.7 (SD 0.1) versus 1.7 (SD 0.1) on warmed-vitrified ovaries $(\mathrm{p}=0.068)$.

\section{DISCUSSION}

In this study, we performed vitrification of human ovarian tissue according to the methods by Kagawa using DMSO and EG as cryoprotectants. ${ }^{7}$ We did not find significantly different in follicles morphology (basal membrane, integrity of follicles and oocyte) between fresh and warmed-vitrified ovarian tissue. Apoptosis could occur through either extrinsic or intrinsic pathways. Bax and Bcl- 2 protein were expressed in granulosa cells, oocytes and stromal of both fresh and warmed-vitrified ovaries. However, vitrification did not increase apoptosis via the intrinsic pathway in follicles.

Numerous studies also reported that there were no ultrastructural changes in oocytes, ovarian follicles, and stromal cells in post-vitrification ovarian tissue. Sheiki, et al. found that vitrification was the best method for ovarian tissue cryopreservation. Vitrification liquid used on that experiment was ethylene glycol as a cryoprotectant. There were also no significant differences among oocytes ultrastructure, granulosa cells, and stromal cells from electron microscope observation. ${ }^{8}$

We reported a non-randomized study comparing slow freezing to vitrification on 20 ovarian biopsies. There were no significant differences in the number and morphology of follicles between two groups. ${ }^{9}$ Kagawa, Silber and Kuwayama also reported the successful technique using cryotissue method with the results of oocyte viability. They also stated there was no significantly different in morphology of ovarian cortex between fresh ovary and warmed-vitrified ovaries. This method used ethylene glycol, DMSO, and sucrose as cryoprotectants in ovarian cortex vitrification technique. ${ }^{7}$

Assesment of ovarian tissue apoptosis can be performed based on morphology, level of apop- tosis, and protein expression related to apoptosis in granulosa cells. Excellent assessment makes us understand the biomolecular process that happened intracellular. Protein expression changes precede morphological changes so that not only morphological changes were assessed but it was also impontant to determine the protein expression changes in ovaries after vitrification. The expression of Bax and Bcl-2 were evaluated because vitrification had been reported to initiate the intrinsic apoptosis pathway. $6,10,11$

Cell signaling process both intrinsic and extrinsic pathway regulates the apoptotic process. Extrinsic pathway is initiated by increasing level of death receptor on cell surface. ${ }^{12,13}$ Death receptor sends apoptotic signal, such as Fas, tumor necrosis factor receptor (TNFR), interferon (IFN), and TNF related apoptosis-induced ligand (TRAIL). ${ }^{12}$ Intrinsic pathway is initiated by mitochondria permeability and the release of pro-apoptotic molecule into cytoplasm without initiation from death receptor. Anti-apoptotic protein, such as Bcl-2 and Bcl-x contributes as apoptosis regulator which can be found in mitochondria membrane and cytoplasm. The damage of DNA can cause Bcl-2 and Bcl-x loss from mitochondria membrane and pro-apoptosis protein, such as Bax, also Bax replaces this DNA damage. The decrease of $\mathrm{Bcl}-2$ and $\mathrm{Bcl}-\mathrm{x}$ protein level are followed by the rise of mitochondria permeability, causing cytochrome $\mathrm{C}$ released from mitochondria. Cytochrome $\mathrm{c}$ will bind to Apaf-1 protein (apoptotic protease activating factor-1) and caspase- 9 and later, this binding will activate caspase cascade and induce cell death. ${ }^{12,13}$

This study showed that vitrification did not affect the morphology of pre-antral follicles. The expression of Bax and Bcl-2 protein on both ovarian cortex was still the same through this vitrication process. Wiweko B also reported that pre-antral follicle vitrification did not increase caspase- 3 and FasL expression. ${ }^{6}$ There were no significant changes between pro-apoptosis mRNA gen (FasL, Bax, p53, and caspase-3) and anti-apoptosis gen (Bcl-2) in both fresh and warmed-vitrified ovaries. Abdollahi, et al. also reported the similar result. ${ }^{14}$

\section{CONCLUSION}

Ovarian tissue vitrification does not affect the Bax and $\mathrm{Bcl}-2$ expression on human ovary. 


\section{REFFERENCES}

1. Sonmezer M, Oktay K. Fertility preservation in female patients. Hum Reprod Update. 2004; 10(3): 251-66.

2. Donnez J, Bassil S. Indications for cryopreservation of ovarian tissue. Hum Reprod Update. 1998; 4(3): 248-59.

3. Chang HJ, Suh CS. Fertility preservation for women with malignancies: current developments of cryopreservation. J Gynecol Oncol. 2008; 19(2): 99-107.

4. Demeestere I, Simon P, Emiliani S et al. Fertility Preservation: Successful Transplantation of Cryopreserved Ovarian Tissue in a Young Patient Previously Treated for Hodgkin's Disease. Oncol. 2007; 12(12): 1437-42.

5. Jadoul P, Dolmans MM, Donnez J. Fertility preservation in girls during childhood: is it feasible, efficient and safe and to whom should it be proposed? Hum Reprod Update. 2010; 16(6): 617-30.

6. Wiweko B. Upaya preservasi fungsi ovarium dengan melakukan vitrifikasi korteks dan folikel pre-antral. Jakarta: Universitas Indonesia. 2014.

7. Kagawa N, Silber S, Kuwayama M. Successful vitrification of bovine and human ovarian tissue. Reprod Biomed Online. 2009; 18(4): 568-77.
8. Sheikhi M HK, Niklasson B, Lundqvist M et al. Clinical grade vitrification of human ovarian tissue: an ultrastructural analysis of follicles and stroma in vitrified tissue. Hum Reprod. 2011; 26(3): 594-603.

9. Keros V XS, Hultenby K, Pettersson K et al. Vitrification versus controlled-rate freezing in cryopreservation of human ovarian tissue. Hum Reprod Update. 2009; 24(7): 1670-83.

10. Mazoochi T, Salehnia M, Pourbeiranvand S et al. Analysis of apoptosis and expression of genes related to apoptosis in cultures of follicles derived from vitrified and non-vitrified ovaries. Mol Hum Reprod. 2009; 15(3): 155-64.

11. Liu H-C, He Z, Rosenwaks Z. Mouse Ovarian Tissue Cryopreservation Has Only a Minor Effect on In Vitro Follicular Maturation and Gene Expression. J Assisted Reprod Genetics, 2003; 20(10): 421-31.

12. Hussein MR. Apoptosis in the ovary: molecular mechanisms. Hum Reprod Update. 2004; 11(2): 162-78.

13. Lumongga F. Apoptosis. Medan: USU; 2008.

14. Maasoume Abdollahi MS, Saghar Salehpour, Nassim Ghorbanmehr. Human Ovarian Tissue Vitrification/Warming Has Minor Effect on the Expression of Apoptosis-Related Genes. Iranian Biomed J. 2013; 17(4): 179-86. 